\title{
Don't Unleash the Privateers!: \\ Privateering is NOT Legal under Contemporary International Law
}

\author{
Leon Y. Xiao ${ }^{[0000-0003-0709-0777] *}$ \\ <leon.xiao.y@gmail.com> \\ *: Durham Law School, Durham University, Palatine Centre, Stockton Rd, Durham, \\ United Kingdom DH1 3LE
}

Content Type: Letter to the Editor

Word count: 497

Conflict of Interest Declaration: None

18 May 2020 
To the Editor:

Cancian and Schwartz's warmongering article 'Unleash the Privateers!,' based on Schwartz's defective and biased legal analysis in 'U.S. Privateering Is Legal,' has unsurprisingly generated significant public attention, including in the People's Republic of China.

Cancian and Schwartz's proposal to revive privateering is plainly contrary to Article 2(4) of the United Nations Charter which prohibits the threat and the use of force between member states. The practical, political and economic implications of illconceived state-sponsored piracy, such as retaliation by the Chinese against this provocation, and the impact that the unilateral adoption of such a policy by the US may cause on world peace, have already been identified and addressed by others. This Letter instead scrutinises their legal analysis.

Schwartz's legal analysis is flawed because he unequivocally and without reservation rejected and dismissed the established legal literature's universally held understanding that customary international law prohibits piracy, including privateering. Schwartz must have appreciated that he was arguing against the literature by providing a radical, alternative interpretation, given that he cited some of these contrary sources in footnote 3. Nonetheless, Schwartz failed to give such sources any due consideration; misrepresented his alternative arguments as legal certainties; and failed to disclose that his assertions are radical and likely to be disputed, as this Letter rightfully attempts to do.

Cancian and Schwartz's assertion that 'Privateering is not piracy' because privateering would be legally regulated by domestic law is no longer defensible under contemporary international law. ${ }^{1}$ For example, Article 101 of the United Nations Convention on the Law of the Sea defines piracy as any act of violence or depredation committed on the high seas by a private actor acting for private ends. Privateering satisfies this contemporary definition: commission by domestic law is no longer a defence to this international crime as the privateer is a private actor, albeit licensed, acting for their private financial ends. Schwartz omitted that despite

\footnotetext{
${ }^{1}$ For the historical perspective, see Eugene Kontorovich, The Piracy Analogy: Modern Universal Jurisdiction's Hollow Foundation, 45 HARVARD INTERNATIONAL LAW JOURNAL 183-238, 210-223 (2004).
} 
Congress having the enumerated power to 'define and punish' piracy, ${ }^{2}$ Congress defines and prohibits piracy only in accordance with 'the law of nations, ${ }^{3}$ rather than with an alternative national definition which excludes privateering. Congress's power to 'grant Letters of Marque and Reprisal' ${ }^{4}$ is an anachronism that should either be repealed or never again applied, as has been the US's position since $1815 .{ }^{5}$

The utmost important legal issue that Schwartz omitted is that piracy is recognised by the legal literature as being prohibited by non-derogable jus cogens, ${ }^{6}$ in addition to being 'only' prohibited by customary international law. ${ }^{7}$ Jus cogens or peremptory norms are fundamental principles that cannot be deviated from, and have special status as compelling law and prevent the US from relying on any of its potential objections to the applicability of customary international law against it, such as the persistent objector rule that Schwartz's argument relied on. ${ }^{8}$ Accordingly, Schwartz's argument fails.

The US can never revive privateering without breaching contemporary international law. Whatever the solution to the conflict between China and the US may be, it is not state-sponsored piracy.

\footnotetext{
${ }^{2}$ U.S. Const. Article I, § 8, cl. 10.

${ }^{3} 18$ U.S. Code $\S 1651$.

${ }^{4}$ U.S. Const. Article I, § 8, cl. 11.

${ }^{5}$ Theodore T. Richard, Reconsidering the Letter of Marque: Utilizing Private Security Providers Against Piracy, 39 Public ConTRACT LaW JoURnal 411-464, n 121 (2010).

${ }^{6} \mathrm{M}$. Cherif Bassiouni, International Crimes: "Jus Cogens" and "Obligatio Erga Omnes", 59 LAW AND CONTEMPORARY PROBLEMS 63-74, 68 (1996).

${ }^{7}$ M. CHERIF BASSIOUNI, CRIMES AGAINST HUMANITY IN INTERNATIONAL CRIMINAL LAW 514-516 (1999).

${ }^{8}$ Inter-American Commission on Human Rights, Domingues v United States, Report No 62/02, Merits Case 12.285, para 85 (2002), http: / / www.cidh.org/ annualrep/ 2002eng/USA.12285.htm (last visited May 18, 2020).
} 
Proceedings Should Include a Disclaimer with Opinionated Articles

\author{
Leon Y. Xiao [0000-0003-0709-0777]* \\ <leon.xiao.y@gmail.com> \\ *: Durham Law School, Durham University, Palatine Centre, Stockton Rd, Durham, \\ United Kingdom DH1 3LE
}

Content Type: Letter to the Editor

Word count: 265

Conflict of Interest Declaration: None

18 May 2020 
To the Editor:

The Naval Institute is easily incorrectly associated with the US Navy, Military and Government because of its official-sounding name and it being based at the United States Naval Academy. In future, Proceedings should include a disclaimer with opinionated articles which explicitly states that the opinions expressed are only those of the author(s) and not that of the US Navy, Military or Government to prevent spreading potential misunderstanding and unnecessary disagreement. This would be in accordance with the policies of most other publications.

Proceedings' submission guidelines page does admirably note that: 'The Naval Institute is not an agency of the U.S. government; the opinions expressed in these pages are the personal views of the authors.' However, the same disclaimer is absent from each article's webpage which means that most readers, who will only read the article, will never see this disclaimer nor appreciate its implications.

Indeed, the personal opinion expressed by Cancian and Schwartz in their Article, 'Unleash the Privateers!,' has been misconstrued and mistranslated, unfairly or not, by Chinese-language media as warmongering expressions of the 'US Military.' ${ }^{1}$ This has led to misunderstanding by Chinese netizens, and unnecessarily offended amity by sowing distrust and disharmony between the two countries, contrary to the universally shared goal of peaceful resolution of all conflicts. A disclaimer should now be added to the 'Unleash the Privateers!' Article to avoid causing further confusion.

All reasoned and evidenced personal opinions should be rightfully welcomed to provide a public platform for discussion and debate; however, in future, Proceedings should always include a disclaimer with all articles to avoid similar misunderstandings.

\footnotetext{
${ }^{1}$ For example, see Zhuo Gao，美军又开新脑洞：战时化整为零当海盗，专门抢劫中国商船 [US Military's New Strategy: Turning into Pirates During War to Specifically Rob Chinese Merchant Ships], https:/ / baijiahao.baidu.com/s?id=1663853646117227083 (last visited May 18, 2020); 军院 34 号 [Military Academy No. 34], 难怪称为当代海盗! 美军刊物刚公开发文, 竟设想劫掠中国商船 [No surprise they are referred to as contemporary pirates! Newly published US Military publication envisages robbing Chinese merchant ships], https: / / baijiahao.baidu.com/s?id=1663554785221820953\&wfr=spider\&for=pc (last visited May 18, 2020).
} 